\title{
Enterprise Ownership and Environmental Control Effects
}

\author{
Meizhong Zhao \\ School of Economics, Jinan University, Guangzhou, China \\ Email: acjnuzmz@163.com
}

How to cite this paper: Zhao, M.Z. (2018) Enterprise Ownership and Environmental Control Effects. Modern Economy, 9, 1511-1519.

https://doi.org/10.4236/me.2018.99095

Received: August 6, 2018

Accepted: September 1, 2018

Published: September 4, 2018

Copyright (C) 2018 by author and Scientific Research Publishing Inc. This work is licensed under the Creative Commons Attribution International License (CC BY 4.0).

http://creativecommons.org/licenses/by/4.0/

\section{(c) (i) Open Access}

\begin{abstract}
This paper measures the elasticity of the fixed assets investment of state-owned enterprises, private enterprises and foreign-funded enterprises in China, and analyzes the impact of rising environmental control costs on fixed asset investment decisions of three types of enterprises. The study found that during the inspection period, private enterprises had the greatest elasticity of rising environmental control costs, and state-owned enterprises had the least elasticity; the impact of rising environmental control costs on state-owned enterprises and private enterprise investment is positive, and the impact on foreign-funded enterprises is negative. Therefore, we suggest that for private enterprises, the government can give tax incentives or supporting arrangements. We should avoid private enterprises facing the pressure of environmental control costs, and choose to withdraw from the market because of insufficient policy support.
\end{abstract}

\section{Keywords}

Forms of Ownership, Fixed Assets, Environmental Regulation

\section{Introduction}

Currently, economies around the world are advocating a low-carbon model. China is also actively pursuing a low-carbon economy model. The State Council issued the "Three-Year Action Plan to Win the Blue Sky Defense War" on July 3, 2018. This plan clearly shows that China will adopt six measures in three years, and by 2020 , the ratio of days with good air quality in cities in China will reach above $80 \%$. From a dynamic point of view, Porter pointed out that the rational setting of environmental control policies can stimulate enterprises to generate innovative compensation effects including products and production processes [1]. In this way, companies can achieve a state of simultaneous improvement in 
environmental performance and economic performance. Under the tightening of environmental control pressures, the purpose of this paper is to study the performance of fixed-asset investment in different ownership enterprises when faced with rising environmental control costs. In the process of China's economy gradually shifting from a planned economy to a market-oriented economy, enterprises can be divided into state-owned enterprises, private enterprises and foreign-invested enterprises according to their different ownership structures. These three types of enterprises have different investment performances because of the different ownership and business decision-making orientations, so these enterprises play different roles in promoting the rapid development of the economy. State-owned enterprises are mainly based on policy orientation, private enterprises are mainly cost-oriented, and foreign-invested enterprises are mainly market-oriented. The conclusions of this paper will provide useful enlightenment for the corresponding policy support for investment entities that are more sensitive to the rising cost of environmental regulation.

The follow-up study of the article is as follows: the second part will review the research literature on environmental regulation and fixed asset investment; the third part introduces relevant variables, data sources and measurement models; the fourth part will conduct empirical analysis; finally, the research conclusions of the article will be carried out.

\section{Literature Review}

The choice of fixed asset investment is not only an important economic decision of different ownership enterprises, but also the main research object of scholars. At present, domestic and foreign literature mainly studies the impact of environmental regulation on foreign direct investment (FDI). Chichilnisky, Copeland, and Taylor proposed the Polling Haven Hypothesis. The hypothesis states that strict environmental regulations in developed countries can seriously affect the production costs of enterprises, so companies are more inclined to turn highly polluting factories into developing countries with environmental control advantages [2]. Levinson analyzed the effect on this basis: First, trade liberalization will bring about devastating competition "running to the bottom line of environmental control"; Second, trade liberalization will move highly polluting factories to countries with loose environmental regulations [3]. Regarding the impact of FDI on China's environment, domestic scholars have also tested it from empirical aspects. Pan and Yu believed that the increase in pollution in Shanghai and Jiangsu Province was caused by the large-scale inflow of FDI [4]. Chen and Zhu et al. reckoned from the perspective of local decentralization that local governments are under pressure from economic development and tend to develop loose environmental protection policies in order to attract FDI inflows [5]. However, some studies have proved that the inflow of FDI has a positive impact on the improvement of China's environmental quality. Bao, et al., using the industrial data from 2001 to 2006 to conduct an empirical test, refuted the 
fact that the pollution paradise hypothesis was established in China [6]. Sheng and $\mathrm{Lu}$ empirically verified that the technical effect of the inflow of FDI led to a significant reduction in industrial sulfur dioxide emissions through the establishment of the Copeland-Taylor model [7].

At present, domestic research on fixed asset investment mainly focuses on the factors affecting fixed asset investment and investment efficiency. Liu and $\mathrm{Wu}$ use absolute and relative models to believe that fixed asset investment is most sensitive to imports and exports [8]. Cui conducted an empirical test on four investment behavior theories, and concluded that there is a positive correlation between investment and gross national product [9]. Chen and Huang considered that before 1978, state-owned enterprises drove the local economy to grow faster [10]. After 1978, state-owned enterprises drove the local economy to grow at a slower rate. $\mathrm{Wu}$ pointed out that the private enterprise has more advantages in terms of innovation investment and efficiency than state-owned and foreign-funded enterprises [11].

In summary, previous studies have focused on the impact of environmental regulation on foreign direct investment and its location distribution, or on the factors affecting fixed asset investment. Few scholars have conducted a comprehensive investigation of both aspects. The contributions of this paper mainly have two points. First, systematically compare the differences between the three types of ownership enterprises in the face of rising environmental control costs, and make up for the deviation caused by the analysis from a single perspective. Second, this paper adopts the dynamic GMM method, which not only examines the impact of environmental governance costs on investment of different ownership enterprises, but also examines the impact of economic development level, labor cost and urbanization level on investment.

\section{Methodology}

The above theoretical analysis shows that the level of environmental regulation does have a significant impact on the choice of corporate investment. Previous studies have shown that regional economic development levels, labor costs and urbanization levels are also important factors affecting fixed asset investment. This paper selects per capita national income, urban unit employment wages and urbanization rate indicators as control variables, and analyzes the impact of changes in the basic conditions of the business environment on fixed assets. Among them, the urbanization rate is measured by the ratio of the non-agricultural employment population to the total population. On this basis, this paper uses three different investment entities and sample data from 29 provinces to empirically test the theoretical hypothesis.

1) Environmental regulation cost

ERCi, $t$-The investment amount of industrial pollution sources in the period of China's $i$ provinces. Environmental control is the policy provisions formulated by different provinces in China for the purpose of protecting the environ- 
ment or the input of pollution source management costs. As the core explanatory variable of this paper, at present, scholars' measurement of environmental regulation is mainly from three aspects: environmental protection legislation, policy implementation and supervision and enforcement. First, from the perspective of environmental protection legislation, Liu measured the intensity of environmental control by collecting environmental regulations and regulations promulgated by various provinces and cities [12]. Second, regarding policy implementation, the academic community is currently examining the two aspects of sewage charges and pollution control investment. A more representative example is Antweiler et al. using per capita GDP in each region as a surrogate for regulation [13]. Zhang et al. used environmental pollution control costs as a quantitative indicator of environmental regulation [14]. Jiang et al. and Zhou et al. used a linear standardization method to perform a weighted average treatment of unit pollution control costs in various regions to obtain environmental control levels [15] [16]. Third, from the perspective of supervision and law enforcement, Fu and $\mathrm{Li}$ and Tang, based on the actual pollution level of "three wastes" in different regions of China, used the comprehensive index method to construct a regional environmental control comprehensive index [17] [18]. In order to explore the impact of environmental control costs on different ownership enterprises, we refer to Zhang to measure the cost of environmental control by using pollution control costs in various regions, that is, industrial pollution source management investments [19].

2) Economic development

PGDPi, $t$-The per capita national income level of China's $i$ provinces. At present, scholars focus on the impact of economic development on investment, mainly on the impact of foreign direct investment in China. Zhu et al. believe that foreign direct investment is more attractive in areas with higher economic development levels [20]. In the eyes of foreign investors, these regions have greater market potential and stronger purchasing power per capita. Although environmental control pressures are greater in these regions, foreign investors are more willing to invest in these regions under the strong market appeal.

3) Labor cost

WAGEi, $t$-The wages of urban unit employees in the $i$-province period in China. According to traditional economic theory, labor costs are an important consideration in measuring the comparative advantage of a region or country. Combined with the fact that China has always been open to foreign investment, the more obvious the difference in labor costs between the two countries, the easier it is to attract foreign investors to invest in China. But for private enterprises, labor costs are not an important reference indicator compared to other factors. When the labor supply intensified in the labor market, the private enterprises in the coastal areas have certain influence, but the overall situation is not significant. This paper measures the actual labor costs of each region by collecting the wages of the employed persons in the urban units of each province 
and removing the influence of inflation.

4) Urbanization level

Urbani, $t$-The urbanization rate of China's $i$ provinces during the t period. The level of urbanization reflects the concentration of population in urban areas. For foreign-funded enterprises, areas with higher urbanization rates mean that the economy is richer and people have higher requirements for quality of life. The greater the obstacles to the entry of highly polluting foreign-funded enterprises. However, for private enterprises, $\mathrm{Wu}$ et al. pointed out that only when the urbanization rate is higher than $34.4 \%$, private enterprises will have a greater impetus to local economic development [21].

\section{Analysis}

In order to empirically test the impact of environmental control costs on fixed asset investment of different ownership enterprises, this paper constructs the following dynamic panel measurement model,

$$
\mathrm{Cap}_{i, t}=\beta_{0}+\beta_{1} \mathrm{Cap}_{i, t-x}+\beta_{2} \mathrm{ERC}_{i, t}+\psi X+u_{i}+\varepsilon_{i, t}
$$

In the above formula, $i$ and $t$ represent the observed value of the $t$-th period of the $i$ region, and $x$ is the number of lag periods of the interpreted variable. Capi, $t$ is the amount of fixed assets investment in the period $t$ of different investment entities. In order to reduce the time series dimension and study the elasticity, the legitimization process was carried out during the empirical test. ERC is a variable that represents the cost of environmental regulation, $X$ is the control variable. The sample period of the study was 2005-2015, and the sample interval was 29 provinces (there were missing statistics in Tibet and Xinjiang). The data in this article are from the China Environmental Statistics Yearbook, China Statistical Yearbook and China Population and Employment Statistics Yearbook.

This paper uses Stata13.0 software to estimate the panel model of the above formula. Table 1 reports the descriptive statistics for each variable. Due to the characteristics of the short panel of data in this paper, this model is estimated by the two-step system generalized moment estimation method (Twostep-SGMM) proposed by Arellano and Bond, Arellano and Bover. The estimated results are shown in Table 2 [22] [23]. It can be seen from Table 2 that the disturbance term after the difference of the three models has a first-order sequence autocorrelation ( $\mathrm{P}$ value is less than 0.1 ) and the second-order sequence autocorrelation does not exist ( $\mathrm{P}$ value is greater than 0.1 ). This is in line with the preconditions for using the system GMM method. Secondly, since 84 tool variables are used in this paper, the Sargan test is used to test whether the instrument variables are over-identified. From the results in Table 2, the Sargan test accepts the null hypothesis that "all instrumental variables are valid" at a $10 \%$ significance level, so the instrumental variables are valid.

\section{Discussion}

Next, we analyze the three sets of results. First of all, from the perspective of 
Table1. The descriptive statistics results.

\begin{tabular}{cccccc}
\hline Variables & Mean & Std. Dev. & Max & Min & Obs. \\
\hline LnCap $_{\text {state }}$ & 7.5342 & 0.8139 & 9.0804 & 4.9513 & 319 \\
LnCap $_{\text {private }}$ & 7.0661 & 1.3645 & 9.9600 & 2.9077 & 319 \\
LnCap $_{\text {Foreign }}$ & 5.6466 & 1.3425 & 8.3294 & 2.1018 & 319 \\
LnERC & 2.5862 & 0.9990 & 4.9530 & -0.9163 & 319 \\
LnPGDP & 10.2846 & 0.6257 & 11.5895 & 8.5898 & 319 \\
LnWage & 10.4272 & 0.4513 & 11.6208 & 9.5243 & 319 \\
LnUrban & 3.9195 & 0.2595 & 4.4954 & 3.2910 & 319
\end{tabular}

Table2. The results of dynamic panel model.

\begin{tabular}{|c|c|c|c|}
\hline Variables & State-owned & Private & Foreign \\
\hline Lag 1 & $\begin{array}{c}0.9618^{* * *} \\
(0.0329)\end{array}$ & $\begin{array}{c}0.9800^{* * *} \\
(0.0647)\end{array}$ & $\begin{array}{c}0.6823^{* * *} \\
(0.0821)\end{array}$ \\
\hline Lag 2 & $\begin{array}{c}-0.1672^{* * *} \\
(0.0613)\end{array}$ & $\begin{array}{c}0.0503 \\
(0.0671)\end{array}$ & $\begin{array}{c}0.2626^{* * *} \\
(0.0465)\end{array}$ \\
\hline Lag 3 & $\begin{array}{c}0.1731^{* * *} \\
(0.0436)\end{array}$ & $\begin{array}{c}-0.1085^{\star *} \\
(0.0543)\end{array}$ & $\begin{array}{c}-0.1748^{*} \\
(0.0957)\end{array}$ \\
\hline ERC & $\begin{array}{c}0.0370^{* * *} \\
(0.0075)\end{array}$ & $\begin{array}{c}0.0557^{* * *} \\
(0.0061)\end{array}$ & $\begin{array}{c}-0.0551^{\star * *} \\
(0.0161)\end{array}$ \\
\hline PGDP & $\begin{array}{c}-0.8557^{* * *} \\
(0.0935)\end{array}$ & $\begin{array}{c}0.2766^{* * *} \\
(0.0959)\end{array}$ & $\begin{array}{c}0.7308^{* * *} \\
(0.1944)\end{array}$ \\
\hline Wage & $\begin{array}{c}0.4431^{* * *} \\
(0.0992)\end{array}$ & $\begin{array}{l}-0.1333 \\
(0.1199)\end{array}$ & $\begin{array}{c}-0.7019^{* * *} \\
(0.1305)\end{array}$ \\
\hline Urban & $\begin{array}{c}1.1234^{* * *} \\
(0.3042)\end{array}$ & $\begin{array}{c}-0.6805^{* * *} \\
(0.2535)\end{array}$ & $\begin{array}{c}-0.0586 \\
(0.295)\end{array}$ \\
\hline Sargan test & $\begin{array}{c}26.4383 \\
(1.00)\end{array}$ & $\begin{array}{c}26.8706 \\
(1.00)\end{array}$ & $\begin{array}{c}21.4642 \\
(1.00)\end{array}$ \\
\hline $\operatorname{AR}(1)$ & $\begin{array}{l}-2.9749 \\
(0.0029)\end{array}$ & $\begin{array}{c}-3.17 \\
(0.0015)\end{array}$ & $\begin{array}{l}-2.4688 \\
(0.0136)\end{array}$ \\
\hline $\operatorname{AR}(2)$ & $\begin{array}{c}0.2791 \\
(0.7802)\end{array}$ & $\begin{array}{l}-1.5565 \\
(0.1196)\end{array}$ & $\begin{array}{c}0.1235 \\
(0.9017)\end{array}$ \\
\hline Observations & 232 & 232 & 232 \\
\hline
\end{tabular}

Note: $(1){ }^{* * *}, * *, *$ represents statistical significance at the $1 \%, 5 \%$, and $10 \%$ levels, respectively. The value in parentheses below the regression coefficient is the standard error. (2) The Sargan test column is the outcome of the instrumental variable. AR (1) and AR (2) respectively show the results of the Arellano-Bond autocorrelation test.

absolute value, private enterprises have the greatest flexibility when the three different ownership structures face rising environmental controls. This is also in line with our expectations and private enterprises are cost-oriented. With the intensification of China's environmental protection policies and the increasing pressure on environmental regulations, private enterprises are also most sensitive to environmental control costs when they choose to build factories or increase new investment in fixed assets. In addition, we found that state-owned enterprises have the least flexibility. There are two development orientations for state-owned enterprises in China. First, for the needs of industrial development, 
and second, to shoulder the responsibility of stimulating economic growth and ensuring employment in the provinces. Therefore, state-owned enterprises are more concerned about how to balance all aspects of national economic development. If a region has basic conditions for the development of emerging industries or natural resources, and the entry of state-owned enterprises can drive the growth of enterprises in the region or improve the entire industrial chain, then state-owned enterprises will still choose to enter. At the same time, we also found that for state-owned enterprises and private enterprises, with the rise of environmental control costs, fixed asset investment is rising. Among them, for every unit of environmental pollution control cost increase, private enterprise fixed assets investment will increase by about $0.056 \%$, while state-owned enterprises will increase by $0.037 \%$. Therefore, environmental regulation will have a negative impact on state-owned enterprises and private enterprises only when the environmental control costs are high enough to offset the local economic development level, labor costs and urbanization levels.

For foreign-funded enterprises, for every unit of environmental pollution control costs, the fixed assets investment of foreign-funded enterprises will be reduced by about $0.055 \%$. The reason is that as the local environmental control pressure increases, it will increase the production cost of the enterprise. For example, companies will increase the equipment to filter and clean up pollutants or increase research and development spending on energy conservation and emission reduction to reduce the amount of pollutants discharged by enterprises. This also explains to some extent that some provincial and municipal governments have invested in building factories to attract foreign-funded enterprises, and have relaxed the local environmental control "running to the bottom line of environmental control". When companies face environmental regulation, different companies have different labor cost elasticity. For foreign-invested enterprises, the largest increase in labor costs, the fixed-asset investment of foreign-funded enterprises will be reduced by about $0.7019 \%$. In the first two decades of reform and opening up, we have mainly relied on cheap labor and abundant natural resources to attract foreign investment. Therefore, when foreign capital enters the market, labor costs will be the key factor for them to consider. According to the traditional economic theory, the three factors of economic development level, labor level and urbanization level have a significant impact on fixed asset investment. But for private enterprises, the impact of labor costs on them is not significant. We believe that for private enterprises, the level of economic development and the level of urbanization have a greater impact on them. But for foreign-invested companies, it is more about economic development and labor costs than labor costs. As we discussed in the previous article, state-owned enterprises are mainly government-oriented, private enterprises are cost-oriented, and foreign-funded enterprises are market-oriented.

\section{Conclusions}

Based on the data of 29 provinces in China, this paper introduces a dynamic 
panel model by introducing environmental control variables, and analyzes the impact of environmental regulation on fixed asset investment of different ownership enterprises. In order to incorporate the difference and level estimation into a system for research, the empirical analysis of the system GMM dynamic panel data analysis method was adopted. The conclusions and implications of the study are as follows:

The study found that private companies have the greatest flexibility in the face of environmental regulatory pressures. Compared with state-owned enterprises and foreign-funded enterprises, private enterprises have certain disadvantages in terms of policy support, industry entry thresholds and tax reductions. Therefore, we suggest that when private enterprises enter the provinces with greater environmental control pressure, the government can give private enterprises tax incentives or supporting arrangements to prevent private enterprises from opting out of the market due to insufficient policy support. The study also found that the impact of rising environmental control costs on state-owned enterprises and private enterprise investment is positive, and the impact on foreign-funded enterprises is negative. We believe that environmental regulation will have a negative impact on state-owned and private enterprises only when environmental control costs are high enough to offset the competitive advantages of local economic development, labor costs and urbanization levels. For foreign-invested companies, current environmental controls have indeed reduced foreign investment. Therefore, in the process of economic development, local governments should adhere to the concept of green sustainable development, increase environmental protection, and must not allow foreign-funded enterprises to damage the long-term development of the regional economy.

\section{Conflicts of Interest}

The authors declare no conflicts of interest regarding the publication of this paper.

\section{References}

[1] Porter, M.E. and Vander, L. (1995) Towards a New Conception of the Environment Competitiveness Relationship. The Journal of Economics Perspectives, 9, 97-118. https://doi.org/10.1257/jep.9.4.97

[2] Chichilnisky, G. (1994) North-South Trade and the Global Environment. American Economic Review, 84, 112-137.

[3] Levinson, A. and Taylor, S. (2004) Trade and the Environment: Unmasking the Pollution Haven. Memo, Georgetown University, Washington DC, 26-47.

[4] Pan, S.B. and Yu, M.Z. (2005) The Test of Causality between Foreign Direct Investment and Environmental Pollution in Jiangsu, Zhejiang and Shanghai Provinces. International Trade Issues, 12, 74-79.

[5] Chen, G. (2009) FDI Competition, Environmental Regulation and Pollution Sanctuary-Reflections on Chinese Decentralization. World Economic Research, 6, 37-43.

[6] Bao, Q., Lv, Y. and Chen, Y.Y. (2010) Foreign Investment and Environmental Pol- 
lution in China-Experience Research Based on Panel Data of Industrial Industry. Journal of Nankai University: Philosophy and Social Sciences Edition, 3, 93-103.

[7] Sheng, B. and Lu, Y. (2012) The Impact of Foreign Direct Investment on China's Environment-An Empirical Test from Panel Data of Industrial Sector. Social Sciences in China, 5, 54-75.

[8] Liu, H.W. (2016) Study on Local Government Environmental Control Behavior and Industrial Pollution Control Performance. Zhejiang University of Finance and Economics, Hangzhou, 2016.

[9] Cui, S.W. (2012) Analysis of the Factors Affecting China's Fixed Assets Investment. Technology Economics and Management Research, 5, 86-89.

[10] Chen, Y.Y. and Huang, G.H. (2006) Growth Imbalance and Ownership Reform in China. Economic Sciences, 1, 5-19.

[11] Wu, Y.B. (2012) Which Type of Ownership System in China Is the Most Innovative? World Economy, 6, 3-27.

[12] Liu, J.H. and Wu, C.X. (2016) Import and Export, Exchange Rate and Fixed Assets Investment: An Investigation of Absolute Models and Relative Models. International Trade Issues, 5, 121-128.

[13] Antweiler, W., Copeland, B.R. and Taylor, M.S. (2001) Is Free Trade Good for the Environment? American Economic Review, 91, 877-908. https://doi.org/10.1257/aer.91.4.877

[14] Zhang, C., Zhu, G.L. and Yu, T.S. (2011) The Relationship between Environmental Pollution and Economic Growth. Statistical Research, 1, 59-67.

[15] Jiang, F.X., Wang, Z.J. and Bai, J.H. (2013) The Dual Effect of Environmental Regulation on Technological Innovation-An Empirical Study Based on Dynamic Panel Data of Jiangsu Manufacturing Industry. China Industrial Economy, 7, 44-55.

[16] Zhou, C.F., Du, Y.W. and Peng, A.P. (2016) Does Environmental Regulation Affect the Location Choice of China's FDI? - An Empirical Study Based on Cost Perspective. World Economy Research, 1, 110-122.

[17] Fu, J.Y. and Li, L.S. (2010) Empirical Research on Environmental Regulation, Factor Endowment and Industrial International Competitiveness-Based on Panel Data of Chinese Manufacturing Industry. Management World, 10, 87-98.

[18] Tang, G.P., Li, L.H. and Wu, D.J. (2013) Environmental Control, Industry Attributes and Enterprise Environmental Protection Investment. Accounting Research, 6, 83-89.

[19] Zhang, W.L. and Han, G.F. (2013) The Impact of Labor Market Development on Labor Cost in China. Financial Research, 7, 1-15.

[20] Zhu, P.F., Zhang, Z.Y. and Jiang, G.L. (2011) FDI and Environmental Regulation: An Empirical Study Based on the Perspective of Local Decentralization. Economic Research, 6, 133-145.

[21] Wu, L.C., Zhang, L.P. and Chen, X.R. (2014) How Private Capital Helps China's Urbanization Process-Microscopic Investigation Based on Panel Threshold Model. Economic Management, 6, 33-44.

[22] Arellano, M. and Bond, S. (1991) Some Tests of Specification for Panel Data: Monte Carlo Evidence and an Application to Employment Equations. Review of Economic Studies, 58, 277-297. https://doi.org/10.2307/2297968

[23] Arellano, M. and Bover, O. (1995) Another Look at the Instrumental Variable Estimation of Error-Components Models. Journal of Econometrics, 68, 29-52.

https://doi.org/10.1016/0304-4076(94)01642-D 